\title{
PENGARUH PDRB, TINGKAT UPAH MINIMUM DAN PENGELUARAN PEMERINTAH TERHADAP PENYERAPAN TENAGA KERJA DI KABUPATEN SIDOARJO
}

\section{Bemby Agung Pratama, Sri Muljaningsih, Kiki Asmara}

Universitas Pembangunan Nasional (UPN) Veteran Jawa Timur, Indonesia

Email: bembyagungpratama@gmail.com,sri_muljaningsih@yahoo.com, kikyasmara25@gmail.com

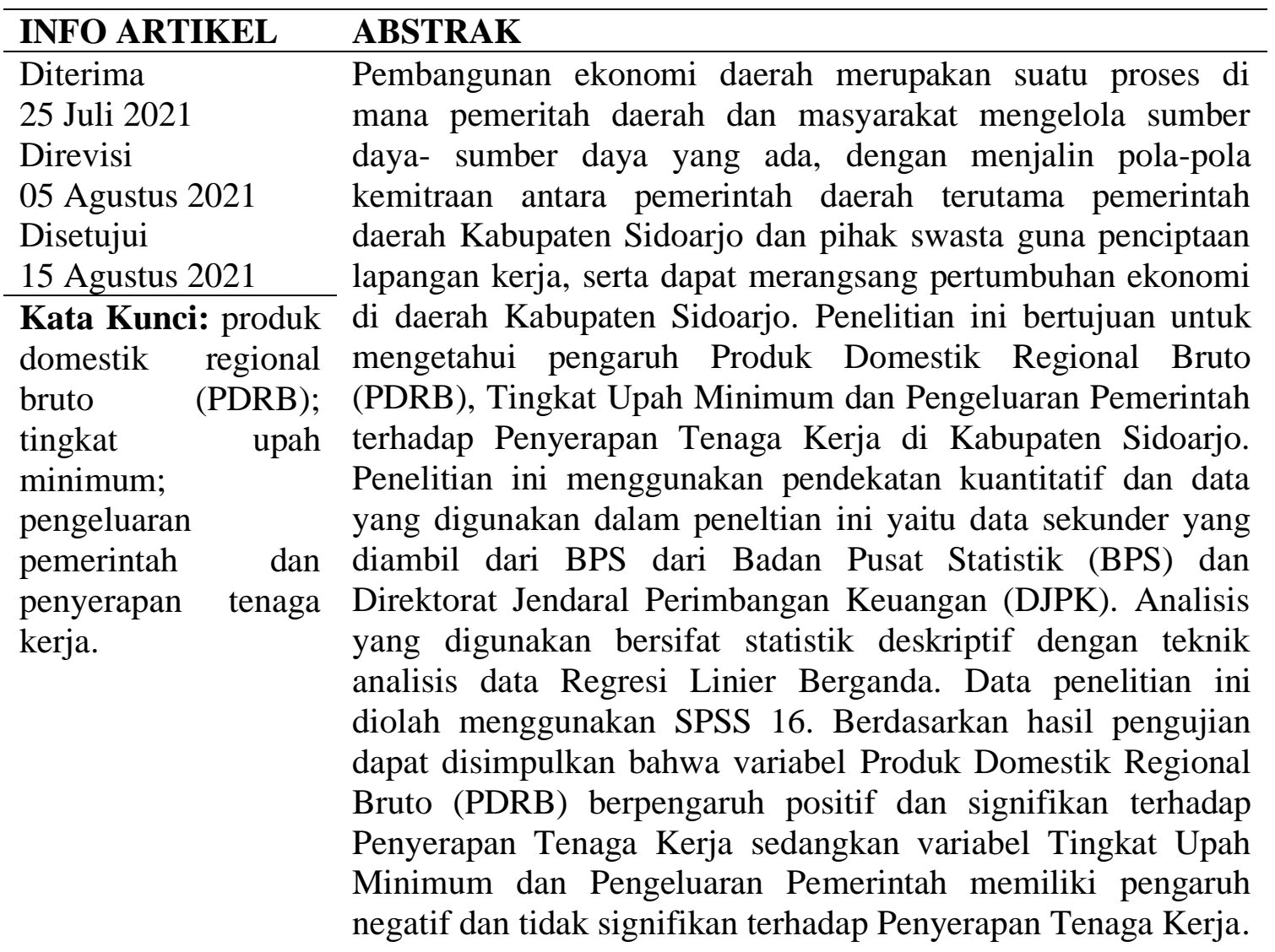

\section{ABSTRACT}

Regional economic development is a process in which the regional government and the community manage existing resources, by establishing partnership patterns between local governments, especially the Sidoarjo Regency government and the private sector for job creation, and can stimulate economic growth in the region. Sidoarjo Regency. This study aims to determine the effect of Gross Regional Domestic Product (GDP), Minimum Wage Level and Government Expenditure on Labor Absorption in Sidoarjo Regency. This study uses a

How to cite:

E-ISSN:

Published by:
Pratama, B. A., Muljaningsih, S., \& Asmara, K. (2021) Pengaruh PDRB, Tingkat Upah Minimum dan Pengeluaran Pemerintah Terhadap Penyerapan Tenaga Kerja Di Kabupaten Sidoarjo. Jurnal Syntax Admiration 2(8). https://doi.org/10.46799/jsa.v2i8.293 2722-5356

Ridwan Institute 


\begin{tabular}{|c|c|}
\hline & $\begin{array}{l}\text { quantitative approach and the data used in this research are } \\
\text { secondary data taken from BPS from the Central Statistics } \\
\text { Agency (BPS) and the Directorate General of Fiscal Balance } \\
\text { (DJPK). The analysis used is descriptive statistics with }\end{array}$ \\
\hline $\begin{array}{lr}\text { Keywords: } & \text { gross } \\
\text { regional } & \text { domestic } \\
\text { product } \quad(\text { GDP }) ; \\
\text { minimum wage level; } \\
\text { government }\end{array}$ & $\begin{array}{l}\text { Multiple Linear Regression data analysis techniques. This } \\
\text { research data is processed using SPSS 16. Based on the test } \\
\text { results, it can be concluded that the Gross Regional Domestic } \\
\text { Product (GRDP) variable has a positive and significant effect } \\
\text { on Labor Absorption while the Minimum Wage Level variable }\end{array}$ \\
\hline $\begin{array}{l}\text { expenditure and } \\
\text { labor absorption }\end{array}$ & $\begin{array}{l}\text { and Government Expenditure has a negative and insignificant } \\
\text { effect on Labor Absorption. }\end{array}$ \\
\hline
\end{tabular}

\section{Pendahuluan}

Pembangunan ekonomi dapat memacu pertumbuhan ekonomi, begitu pula sebaliknya pertumbuhan ekonomi berguna dalam meningkatkan proses pembangunan ekonomi. Menurut (Pratiwi \& Indrajaya, 2019). Pertumbuhan ekonomi didefinisikan sebagai penggunaan faktor produksi yang semakin banyak dalam proses produksi tanpa ada perubahan dalam metode teknis itu sendiri, yang mengarah pada peningkatan produksi masyarakat. Pertumbuhan ekonomi memberikan negara atau pemerintah lebih banyak kesempatan untuk memenuhi kebutuhan dasar rakyat.

Indonesia sendiri dihadapkan oleh beberapa masalah pembangunan ekonomi mulai dari meningkatnya angka kependudukan, meningkatnya jumlah angkatan kerja serta tingginya angka pengangguran. Secara umum masalah ini disebabkan oleh kondisi minimnya ketersediaan lapangan kerja, terutama lapangan kerja sektor formal yang ternyata tidak mampu menyerap bahkan memenuhi jumlah angkatan kerja yang terus bertambah tiap tahunnya. Ini karena ada perbedaan antara pertumbuhan angkatan kerja yang cepat dan kondisi kerja yang tepat. Masalah ini bukan hanya sebatas bidang atau bahkan kesempatan kerja dan juga rendah produktivitas, tetapi jauh lebih penting dari itu ada kegagalan dalam penciptaan lapangan kerja yang tidak sebanding dengan pertumbuhan di masyarakat.

Dalam suatu wilayah pertumbuhan ekonomi dapat di ukur dari Produk Domestik Regional Bruto (PDRB) yang mengindikasikan kesejahteraan penduduk dalam skala regional. Pertumbuhan ekonomi menunjukkan adanya peningkatan produksi barang dan jasa dalam suatu perekonomian, sehingga pertumbuhan ekonomi ini merupakan salah satu indikator penting untuk analisis pembangunan (Nofi Zumaidah \& Soelistyo, 2018).

Ketenagakerjaan jembatan utama yang menghubungkan pertumbuhan ekonomi dan peningkatan kemampuan manusia. Dengan kata lain, perlu dicapai pertumbuhan ekonomi yang berkualitas tinggi dalam arti memberikan manfaat bagi tenaga kerja (Alisman, 2018). Peranan sumber daya manusia sangat penting sehingga suatu daerah yang kaya akan sumber daya alam tidak akan mampu memenuhi kebutuhan masyarakat setempat apabila di wilayah tersebut minim tenaga kerja yang dapat menggali dan mengolah alam tersebut dengan baik. Sebaliknya jika di suatu daerah yang memiliki 
sumber daya modal yang minim, namun memiliki banyak tenaga kerja dengan keterampilan yang tinggi, maka sumber daya alam yang kecil ini dapat diolah secara maksimal sehingga dapat memenuhi kebutuhan masyarakat di daerah tersebut (Rusniati et al., 2018).

Upaya perluasan kesempatan kerja bertujuan untuk menumbuhkan pasar tenaga kerja yang fleksibel, termasuk upaya untuk mengurangi biaya ekonomi yang tinggi untuk menciptakan sebanyak mungkin kesempatan kerja formal, tanpa merugikan pekerja informal, sekaligus mempromosikan pekerja pada pekerjaan dengan produktivitas rendah. ke pekerjaan yang lebih produktif. Pekerja yang masih terlibat dalam pekerjaan dengan produktivitas rendah dapat meningkatkan kesejahteraannya (Effendi, 2014).

Tabel 1

Angkatan Kerja,TPT,TPAK di Kabupaten Sidoarjo

Tahun 2016 - 2019

\begin{tabular}{cccc}
\hline Tahun & $\begin{array}{c}\text { Angkatan Kerja } \\
\text { (Orang) }\end{array}$ & $\begin{array}{c}\text { TPT } \\
(\mathbf{\%})\end{array}$ & $\begin{array}{c}\text { TPAK } \\
(\mathbf{\%})\end{array}$ \\
\hline 2016 & 1.112 .691 & 5,02 & 65,78 \\
\hline 2017 & 1.075 .359 & 4,97 & 64,54 \\
\hline 2018 & 1.094 .650 & 4,79 & 64,53 \\
\hline 2019 & 1.153 .532 & 4,72 & 66,98 \\
\hline
\end{tabular}

Sumber : BPS, Survei Angkatan Kerja Nasional (Sakernas)

Tahun 2016 dan 2019

Berdasarkan tabel di atas jumlah angkatan kerja di Kabupaten Sidoarjo dari tahun 2016 hingga tahun 2019 dapat dikatakan mengalami angka fluktuatif dari tahun ke tahun. Kenaikan angkatan kerja tertinggi di Kabupaten Sidoarjo tertinggi pada tahun 2019 sebesar 1.153 .532 orang. Sedangkan nilai terendah terjadi pada tahun 2017 sebesar 1.075.359 orang.Jumlah angka angkatan kerja tersebut sangat cepat dalam proses perkembangannya.

Kemudian presentase Tingkat Pengangguran Terbuka (TPT) di Kabupaten Sidoarjo menunjukkan angka penurunan dari tahun ke tahun. Untuk nilai tertinggi Tingkat pengangguran terbuka (TPT) terjadi pada tahun 2016 sebesar 5,02\%. Sedagkan nilai terendah terjadi pada tahun 2019 sbesar 4,72\%. Tingkat pengangguran terbuka (TPT) menunjukan tingkat yang relatif stabil hal itu menunjukan bahwa Kabupaten Sidoarjo relatif baik dalam mendorong angkatan kerja untuk bekerja, dan tidak menganggur.

Sedangkan Tingkat Partisipasi Angkatan Kerja (TPAK) menunjukkan angka yang fluktuatif namun cenderung mengalami kenaikan dari tahun ke tahun. Untuk nilai tertinggi Tingkat Partisipasi Angkatan Kerja (TPAK) terjadi pada tahun 2019 sebesar $66,98 \%$. Sedagkan nilai terendah terjadi pada tahun 2018 sbesar $64,53 \%$. Penurunan kinerja ekonomi tersebut, sebagian besar dikarenakan melemahnya tingkat konsumsi pemerintah dan melemahnya harga - harga komoditas. Tinggi atau rendahnya TPAK juga dipengaruhi oleh jumlah penduduk bukan angkatan kerja. 
Dimensi masalah ketenagakerjaan tidak hanya terbatas pada bidang atau kesempatan kerja dan produktivitas yang rendah, tetapi jauh lebih serius dengan penyebab yang berbeda-beda. Dekade terakhir, masalah utama terletak pada kegagalan untuk menciptakan lapangan kerja baru pada tingkat yang sebanding dengan tingkat pertumbuhan output yang tinggi. Seiring dengan perubahan lingkungan ekonomi makro di sebagian besar negara berkembang, tingkat pengangguran yang meningkat pesat terutama disebabkan oleh terbatasnya permintaan akan tenaga kerja (Antiyatna et al., 2016).

Penelitian ini memiliki perbedaan dengan penelitian-penelitian sebelumnya. Perbedaan yang dialakukan oleh peneliti terdahulu dan sekarang yaitu terletak pada variabel yang digunakan yaitu: Penyerapan Tenaga Kerja (Y), Produk Domestik Regional Bruto (X1), Tingkat Upah Minimum (X2), Pengeluaran Pemerintah (X3). Kemudian terletak pada lokasi dan waktu penelitian yang di Kabupaten Sidoarjo pada tahun 2010-2019 dengan angka kuartalan.

Ada beberapa kajian yang relevan dan dimanfaatkan sebagai sumber prespektif dalam penelitian ini yaitu penelitian yang dilakukan (Insana, 2019) dengan judul "Analisis Faktor-faktor yang Mempengaruhi Penyerapan Tenaga Kerja di Kabupaten Takalar". Alat analisis menggunakan analisis model Regresi Berganda (Multiple Regression). Kemudian penelitian dari (Margareth, 2016) dengan judul judul "Analisis Variabel Yang Mempengaruhi Penyerapan Tenaga kerja Pada Industri Kecil Makanan (Studi Pada Industri Kecil Kerupuk Ikan Di Desa Kedungrejo, Kecamatan Jabon, Kabupaten Sidoarjo, Jawa Timur)" Alat analisis yang digunakan adalah analisis regresi berganda dengan menggunakan pendekatan Ordinary Last Square (Ols). Sedangkan penelitian dari (Ganie, 2017) Judul penelitian "Analisis Pengaruh Upah, Tingkat Pendidikan, Jumlah Penduduk Dan PDRB Terhadap Penyerapan Tenaga Kerja Di Kabupaten Berau Kalimantan Timur". Alat analisis yang digunakan adalah regresi linier berganda.

Penelitian ini memiliki tujuan untuk menganalisis beberapa faktor yang dapat mempengaruhi penyerapan tenaga kerja di Kabupaten Sidoarjo. Manfaat dari penelitian ini diharapkan dapat memberikan sedikit gambaran suatu metode dari sekian banyak metode yang berkontribusi dan diharapkan dapat bermanfaat untuk memberi informasi dan bahan pertimbangan kepada pemerintah Kabupaten Sidoarjo untuk lebih memperhatikan kondisi ketenagakerjaan di Kabupaten Sidoarjo.

Berdasarkan penjelasan yang telah diuraikan diatas maka peneliti terdorong untuk melakukan peneletian yang berjudul "Pengaruh Produk Domestik Regional Bruto (PDRB), Tingkat Upah Minimum dan Pengeluaran Pemerintah Terhadap Penyerapan Tenaga Kerja di Kabupaten Sidoarjo". 


\section{Metode Penelitian}

Penelitian ini menggunakan metode deskriptif dan dilakukan dengan analisis kuantitatif. Metode analisis yang digunakan adalah regresi linier berganda. Populasi dalam penelitian ini yaitu seluruh data Produk Domestik Regional Bruto (PDRB), Tingkat Upah Minimum, Pengeluaran Pemerintah dan Tenaga Kerja di Kabupaten Sidoarjo dan Sampel pada penelitian ini yaitu Produk Domestik Regional Bruto (PDRB), Tingkat Upah Minimum, Pengeluaran Pemerintah dan Tenaga Kerja dari tahun 2010-2019 dalam angka kuartalan diambil dari Badan Pusat Statistika Kabupaten Sidoarjo dan Direktorat Jendral Perimbangan Keuangan. Data yang dipakai dalam penelitian ini merupakan data sekunder.

\section{Hasil dan Pembahasan}

\section{A. Hasil Penelitian}

\section{Uji Autokorelasi}

Autokorelasi adalah korelasi antara data observasi yang diurutkan berdasarkan deret waktu (time series) atau data yang diperoleh pada titik waktu tertentu (cross section) (Gujarati, 2010).

\section{Tabel 2}

Model Summary (Nilai DW)

\begin{tabular}{cccccc}
\hline \multicolumn{6}{c}{ Change Statistics } \\
\hline $\begin{array}{c}\text { R Square } \\
\text { Change }\end{array}$ & $\begin{array}{c}\text { F } \\
\text { Change }\end{array}$ & df1 & df2 & $\begin{array}{c}\text { Sig. F } \\
\text { Change }\end{array}$ & $\begin{array}{c}\text { Durbin - } \\
\text { Watson }\end{array}$ \\
\hline .647 & 22.010 & 3 & 36 & .000 & 1.421 \\
\hline \multicolumn{7}{c}{ Sumber : Hasil Output SPSS }
\end{tabular}

Didapatkan nilai $\mathrm{DW}$ tabel adalah sebesar $\mathrm{dL}=1,338$ dan $\mathrm{dU}=1,658$ serta 4-dL= 2,661 Dan 4-dU = 2.341. Berdasarkan hasil analisis, model regresi ini tidak menunjukkan gejala autokorelasi, karena nilai uji DW yang diperoleh adalah 1,421 yang berada pada wilayah antara dL dan dU yang artinya berada pada wilayah keraguan atau ketidakpastian.

\section{Uji Multikolinearitas}

Multikolinearitas mengacu pada adanya hubungan linier yang "sempurna" atau terdefinisi antar variabel bebas Dalam regresi linier berganda, tidak boleh ada hubungan antar variabel bebas (bukan multikolinearitas). (non multikolinieritas).

Tabel 3

Tes Multikolinieritas

\begin{tabular}{ccccc}
\hline Variabel Bebas & Tolerance & VIF & Ketentuan & Keterangan \\
\hline PDRB (X1) & 0,121 & 8,292 & $<10,00$ & $\begin{array}{c}\text { Tidak Terjadi } \\
\text { Multikolinieritas }\end{array}$ \\
\hline $\begin{array}{c}\text { Tingkat Upah } \\
\text { Minimum (X2) }\end{array}$ & 0,103 & 9,677 & $<10,00$ & $\begin{array}{c}\text { Tidak Terjadi } \\
\text { Multikolinieritas }\end{array}$ \\
\hline $\begin{array}{c}\text { Pengeluaran } \\
\text { Pemerintah (X3) }\end{array}$ & 0,593 & 1,686 & $<10,00$ & $\begin{array}{c}\text { Tidak Terjadi } \\
\text { Multikolinieritas }\end{array}$ \\
\hline
\end{tabular}

Sumber : Hasil Output SPSS 
Setelah diadakan pengujian analisis regresi linier berganda diketahui bahwa dari ketiga variabel bebas dengan VIF untuk X1 sebesar 8,292; VIF untuk X2 sebesar 9,677; dan VIF untuk X3 sebesar 1,686 yang berarti dari ketiga variabel bebas lebih kecil dari 10 sehingga dalam model regresi ini tidak terjadi multikolinieritas.

\section{Uji Heterokedastisistas}

Nilai residual regresi linier adalah nilai yang tidak tergantung pada variabel bebas (X). Hal ini dapat diverifikasi dengan menghitung korelasi Rank Spearman antara residual dan semua variabel independen. Bukti heterokedastisitas ada pada tabel berikut:

Tabel 4

Tes Heterokedastisitas

\begin{tabular}{lccc}
\hline \multicolumn{1}{c}{ Variabel } & $\begin{array}{c}\text { Taraf a Sinifikansi } \\
\text { Korelasi Rank } \\
\text { Spearman Sig.(2- } \\
\text { tailed) }\end{array}$ & $>\mid<$ & Taraf a uji \\
\hline PDRB (X1) & 0,921 & $>$ & 0,05 \\
\hline $\begin{array}{l}\text { Tingkat Upah } \\
\text { Minimum (X2) }\end{array}$ & 0,933 & $>$ & 0,05 \\
\hline $\begin{array}{l}\text { Pengeluaran } \\
\text { Pemerintah (X3) }\end{array}$ & 0,756 & $>$ & 0,05 \\
\hline
\end{tabular}

Berdasarkan tabel di atas, tingkat signifikansi koefisien korelasi Rank Spearman variabel independen X1 adalah 0,921, X2 adalah 0,933, dan X3 adalah 0,756.Untuk residual memiliki nilai lebih besar dari 0,05 (tidak signifikan), tidak terdapat hubungan yang signifikan dan variabel yang dijelaskannya. Oleh karena itu, dapat disimpulkan bahwa tidak terdapat heteroskedastisitas pada persamaan tersebut.

\section{Hasil Koefisien Determinasi}

Pada hasil perhitungan diperoleh $\mathrm{R}^{2}=$ Koefisien determinasi sebesar 0,643 artinya $64,7 \%$ dari seluruh pengamatan menunjukkan variabel bebas PDRB $\left(\mathrm{X}_{1}\right)$, Tingkat Upah Minimum $\left(\mathrm{X}_{2}\right)$ dan Pengeluaran Pemerintah $\left(\mathrm{X}_{3}\right)$ mampu menjelaskan variasi variabel terikatnya Penyerapan Tenaga Kerja (Y), sisanya $35,3 \%$ (diperoleh dari $100 \%$ - 64,7\%) adalah dipengaruhi faktor lain yang tidak tampak pada model atau galatnya. 
Pengaruh PDRB, Tingkat Upah Minimum dan Pengeluaran Pemerintah terhadap Penyerapan Tenaga Kerja Di Kabupaten Sidoarjo

5. Hasil Analisis Regresi Berganda

Tabel 5

Hasil Perhitungan Uji Regresi Linear Berganda Coefficients $^{\mathrm{a}}$

\begin{tabular}{ccccc}
\hline & Unstandardized & Coefficients & $\begin{array}{c}\text { Standardized } \\
\text { Coefficients }\end{array}$ \\
\hline Model & B & Std.Error & Beta \\
\hline 1 & (Constant) & 203024.771 & 15649 & \\
\hline PDRB (X1) & 0.002 & 0.001 & 0.792 \\
\hline & Tingkat Upah & -0.004 & 0.015 & -0.083 \\
Minimum (X2) & & 0.000 & -0.151 \\
\hline & $\begin{array}{c}\text { Pengeluaran } \\
\text { Pemerintah } \\
\text { (X3) }\end{array}$ & -3.662 & \\
\hline & & & \\
\hline & & & \\
\hline
\end{tabular}

Sumber : Hasil Output SPSS

Berdasarkan hasil analisis tersebut diperoleh persamaan regresi linier berganda sebagai berikut

$$
Y=203024,771+0,002 X_{1}-0,004 X_{2}-3,3662 X_{3}
$$

Dimana :

$\beta o=$ Konstanta $=203024,771$

Artinya jika diasumsikan X1,X2,dan X3 konstan maka nilai Y (Penyerapan Tenaga Kerja) akan mengalami kenaikan sebesar 203.024,771

$\beta 1=$ Koefisien Regresi X1 = 0,002

Artinya setiap kenaikan X1 (Produk Domestik Regional Bruto) sebesar Rp 1 Juta akan menyebabkan keniakan nilai Y (Penyerapan Tenaga Kerja) sebesar 0,002 orang dengan asumsi X2 dan X3 konstan.

$\beta 2=$ Koefisien Regresi X2 = - 0,004

Artinya setiap kenaikan X2 (Tingkat Upah Minimum) sebesar Rp 1 Juta akan menyebabkan penurunan nilai Y (Penyerapan Tenaga Kerja) sebesar - 0,004 orang dengan asumsi X3 dan X4 konstan.

$\beta 3=$ Koefisien Regeresi X3 $=-3,663$

Artinya setiap kenaikan X3 (Pengeluaran Pemerintah) sebesar Rp 1 Milyar akan menyebabkan penuruunan nilai Y (Penyerapan Tenaga Kerja) sebesar 3,663 orang dengan asumsi X1 dan X2 konstan.

\section{Uji F}

Menurut (Sugiyono, 2014) Uji F merupakan pengujian koefisien regresi secara simultan, pengujian ini dilakukan untuk memahami dan mengetahui pengaruh semua variabel bebas yang dimasukkan dalam model secara bersamasama (dalam waktu yang bersamaan) terhadap variabel terikat. 
Tabel 6

Uji Statistik F

\begin{tabular}{|c|c|c|c|c|c|}
\hline \multicolumn{6}{|c|}{ ANOVA $^{b}$} \\
\hline Model & $\begin{array}{l}\text { Sum of } \\
\text { Squares }\end{array}$ & df & $\begin{array}{l}\text { Mean } \\
\text { Square }\end{array}$ & $\mathbf{F}$ & Sig \\
\hline Regression & 4090610532 & 3 & 1363536844 & 22.010 & $.000^{\mathrm{a}}$ \\
\hline Residual & 2230187384 & 36 & 61949649.6 & & \\
\hline Total & 6320797916 & 39 & & & \\
\hline
\end{tabular}

a. Predictors: (Constant), Pengeluaran Pemerintah (X3), PDRB (X1), Tingkat Upah Minimum (X2)

b. Dependent Variable: Penyerapan Tenaga Kerja (Y)

Sumber : Hasil Output SPSS

Dari tabel diatas dapat diketahui bahwa nilai $\mathrm{F}$ hitung sebesar 22.010 dengan signifikansi $0,000<0,05$, artinya variabel PDRB, Tingkat Upah Minimum dan Pengeluaran Pemerintah secara simultan memiliki pengaruh yang signifikan terhadap variabel Penyerapan Tenaga Kerja, sehingga model tersebut dinyatakan layak/fit. Jika dilihat dari $\mathrm{f}$ hitung diperoleh sebesar 22.010, sedangkan nilai $\mathrm{f}$ tabel $(\mathrm{a}=0,05)$ dengan degree of freedom ( $d f 1)$ adalah 3 (jumlah variabel bebas/k) dan (df2) adalah 36 (n-k-1) maka diperoleh nilai $f$ tabel sebesar 2,87.

\section{Uji T}

Uji-t (test) melakukan uji parsial terhadap koefisien regresi . Pengujian ini dilakukan untuk mengetahui signifikansi parsial pengaruh variabel independen terhadap variabel dependen, dengan asumsi variabel independen lainnya dianggap konstan. (Sugiyono, 2014). Berdasarkan hasil perhitungan SPSS didapat hasil berikut:

\section{Tabel 7}

Hasil Perhitungan Uji t Coefficients $^{\mathrm{a}}$

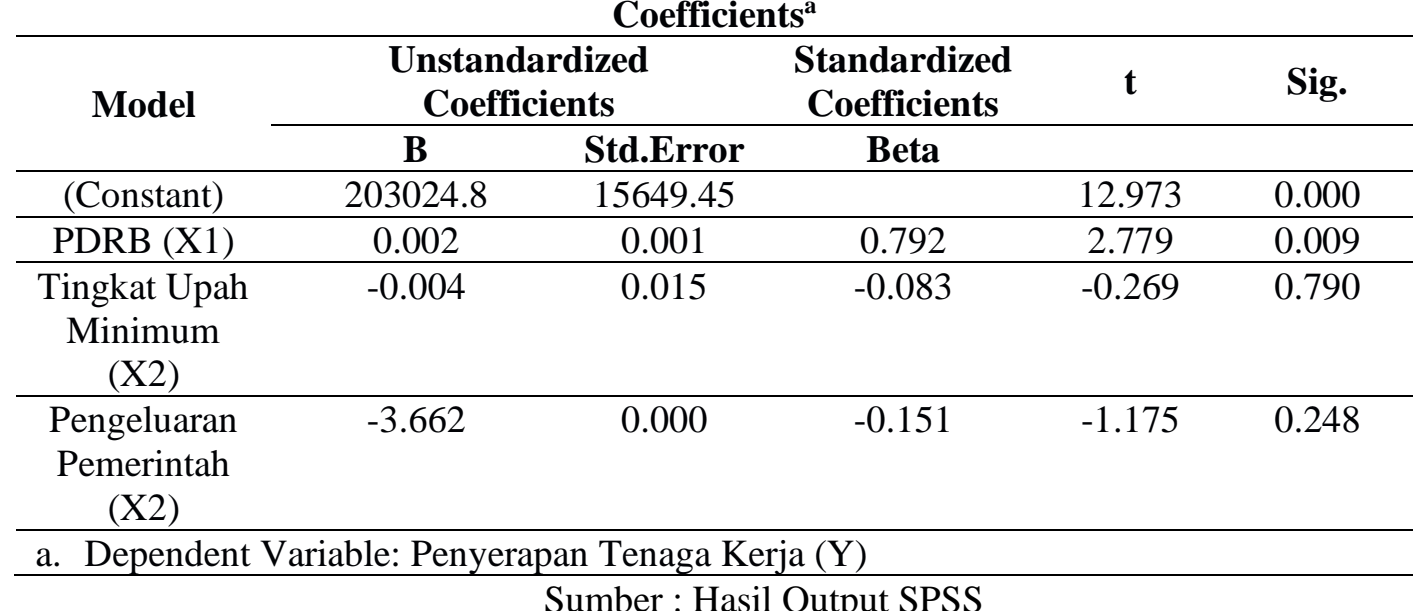

Sumber : Hasil Output SPSS

Berdasarkan hasil perhitungan output SPSS diatas diketahui bahwa pengaruh variabel-variabel independen terhadap variabel dependen sebagai berikut: 
a. Pada output regresi menunjukkan bahwa angka signifikasi untuk variabel PDRB (X1) yaitu $0,009<0.05$ sehingga dapat disimpulkan bahwa terdapat pengaruh secara parsial dan signifikan antara variabel PDRB terhadap Penyerapan Tenaga Kerja.

b. Pada output regresi menunjukkan bahwa angka signifikasi untuk variabel Tingkat Upah Minimum (X2) yaitu 0,790 > 0.05 sehingga dapat disimpulkan bahwa tidak terdapat pengaruh secara parsial dan tidak signifikan antara variabel Tingkat Upah Minimum terhadap Penyerapan Tenaga Kerja.

c. Pada output regresi menunjukkan bahwa angka signifikasi untuk variabel Pengeluaran Pemerintah (X3) yaitu 0,248>0.05 sehingga dapat disimpulkan bahwa tidak terdapat pengaruh secara parsial dan tidak signifikan antara variabel Pengeluaran Pemerintah terhadap Penyerapan Tenaga Kerja.

\section{B. Pembahasan}

\section{Pengaruh Produk Domestik Regional Bruto terhadap Penyerapan Tenaga Kerja}

Berdasarkan hasil pengujian Produk Domestik Regional (X1) secara parsial diperoleh $\mathrm{t}$ hitung sebesar 2,779 $\geq \mathrm{t}$ tabel sebesar 2,028 maka Ho ditolak dan Ha diterima pada level signifikan 5\%.Sehingga secara parsial Produk Domestik Regional Bruto (X1) berpengaruh secara nyata (signifikan) positif terhadap penyerapan tenaga kerja di Kabupaten Sidoarjo. Artinya jika nilai PDRB pada sektor ekonomi yang ada meningkat, maka jumlah tenaga kerja yang tersedia akan meningkat. Dengan pembangunan dan peningkatan ekonomi, pembukaan lapangan kerja baru akan didorong. Tidak hanya dapat meningkatkan sektor ekonomi yang sedang berkembang, tetapi juga dapat mengurangi tingkat pengangguran dengan menyediakan lapangan kerja baru. Hal ini sesuai dengan pandangan (Indradewa \& Natha, 2015) yang menyatakan bahwa apabila Produk Domestik Regional Bruto daerah tersebut mengalami peningkatan permintaan agregat sehingga akan mempengaruhi jumlah tenaga kerja yang akan diserap. Hal ini akan menigkat seiring dengan dorongan sektor usaha untuk menambah produksinya dan akan mempengaruhi tingkat penyerapan tenaga kerja.

\section{Pengaruh Tingkat Upah Minimum terhadap Penyerapan Tenaga Kerja}

Berdasarkan hasil pengujian Tingkat Upah Minimum (X2) secara parsial diperoleh $\mathrm{t}$ hitung sebesar $-0,269<\mathrm{t}$ tabel sebesar 2,028 maka Ho diterima dan Ha ditolak pada level signifikan 5\%, sehingga secara parsial Tingkat Upah Minimum (X2) tidak berpengaruh secara terhadap penyerapan tenaga kerja di Kabupaten Sidoarjo. Artinya besar kecilnya upah akan mempengaruhi tingkat biaya produksi perusahaan. Jika nilai upah tinggi, maka biaya produksi yang tinggi akan menaikkan harga, yang pada gilirannya akan menurunkan permintaan terhadap produk tersebut. Situasi ini memaksa produsen untuk mengurangi jumlah produk yang dihasilkan, yang pada gilirannya mengurangi permintaan tenaga kerja. Hal ini sesuai dengan pendapat (Patriansyah, 2018) bahwa ketika tingkat upah minimum di suatu daerah meningkat, jumlah karyawan cenderung 
menurun. Hal ini karena jika nilai upah tinggi, perusahaan atau industri akan menyusut. Pengurangan tenaga kerja dapat mencegah kenaikan biaya produksi atau mengurangi beban upah yang harus dibayar untuk menaikkan upah minimum dengan mengganti tenaga kerja dengan mesin.

\section{Pengaruh Pengeluaran Pemerintah terhadap Penyerapan Tenaga Kerja}

Berdasarkan hasil pengujian Pengeluaran Pemerintah (X3) secara parsial diperoleh $\mathrm{t}$ hitung sebesar $-1,175 \leq \mathrm{t}_{\text {tabel }}$ sebesar 2,028 maka Ho diterima dan Ha ditolak pada level signifikan 5\% sehingga secara parsial Pengeluaran Pemerintah (X3) tidak berpengaruh secara terhadap penyerapan tenaga kerja di Kabupaten Sidoarjo. Artinya bahwa perubahan nilai pada pengeluaran pemerintah dari anggaran pemerintah daerah dialokasikan di beberapa sector sehingga tidak terfokuskan untuk kegiatan pelatihan kerja maupun pembiayaan yang berhubungan dengan ketenagakerjaan dan tidak memberikan kontribusi yang cukup berarti bagi penyerapan tenaga kerja di Kabupaten Sidoarjo. Hasil penelitian ini sesuai dengan penelitian (Bubi et al., 2018) yang menyatakan bahwa anggaran pemerintah lebih banyak digunakan untuk belanja rutin dan belanja operasional, pembangunan dan perbaikan infrastruktur yang telah ada dan tidak bersifat produktif. Kemudian menurut penelitian Susanti dalam (Damayanti, 2019) mengatakan bahwa pengeluaran pemrintah merupakan aspek penggunaan sumber daya, yang secara langsung dikuasai dan dimiliki oleh pemerintah, dan secara tidak langsung dimiliki oleh masyarakat, yaitu melalui pajak. Pengeluaran pemerintah dapat meningkatkan produksi yang dihasilkan oleh pemerintah. Perekonomian sektoral dapat meningkatkan pendapatan masyarakat, sehingga mendorong permintaan agregat. Produsen membutuhkan tenaga kerja untuk meningkatkan produksi, sehingga menciptakan lapangan kerja baru.

\section{Kesimpulan}

Dari hasil pengujian hipotesa dengan menggunakan analisis regresi linear berganda dapat disimpulkan bahwa berdasarkan perhitungan diperoleh Produk Domestik Regional Bruto $\left(\mathrm{X}_{1}\right)$, berpengaruh secara nyata (signifikan) positif terhadap Penyerapan Tenaga Kerja (Y). Kemudian dari perhitungan diperoleh bahwa Tingkat Upah Minimum $\left(\mathrm{X}_{2}\right)$, tidak berpengaruh secara nyata (signifikan) negatif terhadap Penyerapan Tenaga Kerja (Y). Kemudian dari perhitungan diperoleh bahwa Pengeluaran Pemerintah $\left(\mathrm{X}_{3}\right)$, tidak berpengaruh secara nyata (signifikan) negatif terhadap Penyerapan Tenaga Kerja (Y). 


\section{BIBLIOGRAFI}

Alisman, A. (2018). Analisis Pengaruh Pertumbuhan Ekonomi Dan Pengeluaran Pemerintah Terhadap Penyerapan Tenaga Kerja Di Kabupaten Aceh Barat. Jurnal REP (Riset Ekonomi Pembangunan), 3 (2), 321-333. https://doi.org/10.31002/rep.v3i2.1040. Google Scholar

Antiyatna, dirta pratama, Muhyiddin, nurlina T., \& Soebyakto, bambang bemby. (2016). Pengaruh upah minimum, pertumbuhan ekonomi dan pendididikan terhadap penyerapan tenaga kerja di Provinsi Sumatera Selatan. Jurnal Ekonomi Pembangunan, 14 (1), 8-21. Google Scholar

Bubi, B., Zakiah, W., \& Marpaung, K. (2018). Analysis of Government Expenditures, Private Investment and Gross Regional Domestic Products on Absorption of Labor in Kalimantan: Analisis Pengeluaran Pemerintah, Investasi Swasta Dan Produk Domestik Regional Bruto (PDRB) Terhadap Penyerapan Tenaga Kerja. Journal Magister Ilmu Ekonomi Universtas Palangka Raya: GROWTH, 4 (2), 47-60. Google Scholar

Damayanti, A. D. (2019). Analisis Penyerapan Tenaga Kerja Di Kabupaten/Kota Daerah Istimewa Yogyakarta (Tahun 2012-2016). Google Scholar

Effendi, R. (2014). Analisis Penyerapan Tenaga Kerja Pada Sembilan Sektor Ekonomi di Sumatera Selatan. Jurnal Penelitian Dan Pengembangan Akuntansi, 8 (1), 2552. Google Scholar

Ganie, D. (2017). Analisis Pengaruh Upah Tingkat Pendidikan Jumlah Penduduk Dan PDRB Terhadap Penyerapan Tenaga Kerja Di Kabupaten Berau Kalimantan Timur. Jurnal Eksekutif, 14 (2), 332-354. Google Scholar

Gujarati, J. (2010). Portraits of early career elementary teachers: Examining beliefs about mathematics in the midst of classroom practices. Teachers College, Columbia University. Google Scholar

Indradewa, I. G. A., \& Natha, K. S. (2015). Pengaruh inflasi, PDRB dan Upah Minimum terhadap penyerapan tenaga kerja di provinsi Bali. E-Jurnal Ekonomi Pembangunan Universitas Udayana, 4 (8), 44563. Google Scholar

Insana, N. (2019). Analisis Faktor Faktor Yang Mempengaruhi Penyerapan Tenaga Kerja dI Kabupaten Takalar, Skripsi. Universitas Islam Negeri Alauddin Makassar. Google Scholar

Margareth, M. (2016). Anaslisis Variabel Yang Mempengaruhi Penyerapan Tenagakerja Pada Industri Kecil Makanan (Studi Pada Industri Kecil Kerupuk Ikan di Desa Kedungrejo, Kecamatan Jabon, Kabupaten Sidoarjo, Jawa Timur). Jurnal Ilmiah Mahasiswa FEB, 4 (2). Google Scholar 
Nofi Zumaidah, L., \& Soelistyo, A. (2018). Pengaruh Total Aset, Dana Pihak Ketiga, dan Kredit Pada Bank Umum Terhadap Pertumbuhan Ekonomi Provinsi - Provinsi di Indonesia Pada Tahun 2013 - 2016. Jurnal Ilmi Ekonomi, 2, 251-263. Google Scholar

Patriansyah, A. R. (2018). Analisis Pengaruh Jumlah Penduduk,UMR,PDRB Dan Inflasi Terhadap Penyerapan Tenaga Kerja Di Jawa Tengah Tahun 2011-2016. Google Scholar

Pratiwi, N. P. A., \& Indrajaya, I. G. B. (2019). Pengaruh Pertumbuhan Ekonomi Dan Pengeluaran Pemerintah Terhadap Penyerapan Tenaga Kerja Serta Kesejahteraan Masyarakat Di Provinsi Bali. Buletin Studi Ekonomi, 22. https://doi.org/10.24843/bse.2019.v24.i02.p05. Google Scholar

Rusniati, R., Sudarti, S., \& Agustin, A. F. (2018). Analisis Pengaruh Pertumbuhan Ekonomi dan Upah Minimum terhadap Penyerapan Tenaga Kerja di Kabupaten Malang. Falah: Jurnal Ekonomi Syariah, 3 (2), 34. https://doi.org/10.22219/jes.v3i2.7232. Google Scholar

Sugiyono. (2014). Metode Penelitian Kuantitatif. Kualitatif dan R\&D. CV Alfabeta. Google Scholar

\section{Copyright holder:}

Bemby Agung Pratama, Sri Muljaningsih, Kiki Asmara (2021)

First publication right:

Jurnal Syntax Admiration

This article is licensed under:

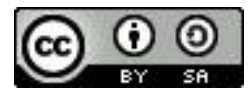

